\title{
Kebijakan Hukum Pidana terhadap Kedaruratan di Situasi Pandemi COVID-19 Sebagai Alasan Pembebasan Bersyarat
}

\author{
Criminal Policy toward Provisional in COVID-19 Outbreak as a \\ Parelo Reason
}

\author{
Muhar Jaya \\ Lembaga Pemasyarakatan Kelas II a Kendari, Kementerian Hukum dan Hak Asasi Manusia \\ E-mail: muharjayaohar@gmail.com
}

\author{
Herman \\ Pascasarjana Universitas Halu Oleo \\ E-mail: man.herman76 @yahoo.com \\ Handrawan \\ Pascasarjana Universitas Halu Oleo \\ E-mail: handrawansaranani84@gmail.com
}

\begin{abstract}
This study aimed at analyzing of policy application of the parole for convicted criminal in the middle COVID-19 outbreaks by mean of Ministrty of Justice and Human Rights with 10 Year 2020 Provision of Assimilation and Integration for Prisoners and Children. In addition, this article examining prevention and treatment of spread of COVID-19 outbreaks toward the ordinancne of Ministrty of Justice and Human Rights of Assimilation and Integration for Prisoners and Children. This paper applied a legal research by means of rule and concept approach. This research revealed that prevention and treatment were not the right solution and it was just temporary only. Ideally, it's should duly overcome social problem and protection. Thus, it is not merely focused on COVID-19 prevention and prison over capacity. Yet in an ideal world, it is justice aspect and deterrent effect that considered as the aim of criminal law. Moreover, this aim was intended not to commit crime as well as to fix offender character.
\end{abstract}

Keywords: Legal Policy; Parole; Assimilation and Integration; Criminalization

Abstrak: Tulisan ini ditujukan pada analisis penerapan kebijakan pembebasan narapidana di tengah pandemi COVID-19 melalui Peraturan Menteri Hukum dan Hak Asasi Manusia Nomor 10 Tahun 2020 tentang Syarat Pemberian Asimilasi dan Hak Integrasi Bagi Narapidana dan Anak. Selain itu, artikel ini menguji Pencegahan dan Penanggulangan Penyebaran COVID-19, serta Keputusan Menteri Hukum dan HAM No. M.HH-19.PK.01.04.04/2020 tentang Pengeluaran dan Pembebasan Narapidana dan Anak Melalui Asimilasi dan Integrasi dalam Rangka Pencegahan dan Penanggulangan Penyebaran COVID-19. Penelitian ini menggunakan penelitian 
hukum melalui pendekatan peraturan undang-undangan dan konsep. Penelitian ini menghasilkan kebijakan guna mencegah penularan dan penyebaran COVID-19 bukan solusi yang tepat dan hanya bersifat sementara. Dalam konsepsi PendekatanKebijakan seharusnya kebijakan pembebasan bersyarat disituasi pandemi COVID-19 ini berupaya untuk mengatasi COVID-19 sebagai masalah-masalah sosial dan masalah kemanusian serta merupakan bagian dari upaya memberikan perlindungan kepada masyarakat. Sehingga pembebasan narapidana jangan hanya difokuskan untuk sekedar mencegah COVID-19 dan over kapasitas penjara, namun tetap harus memperhatikan aspek keadilan dan efekjera sebagai tujuan pemidanaan yaitu untuk memperbaiki pelaku agar menjadi baik dan tidak mengulangi kejahatannya kembali.

Kata kunci: Kebijakan Hukum; Pembebasan Bersyarat; Asimilasi dan Integrasi; Pemidanaan

\section{PENDAHULUAN}

Pembebasan narapidana dilatarbelakangi oleh Komisi Tinggi PBB untuk HAM, yang mendorong pembebasan tahanan di negara-negara dengan kondisi penjara yang mengkhawatirkan sehingga Indonesia bukan satu-satunya negara yang menerapkan kebijakan untuk membebaskan narapidana di tengah pandemi COVID-19. Penyebaran COVID-19 telah menekan sistem peradilan pidana secara global dan menyebabkan banyaknya pembebasan narapidana.

Kementerian Hukum dan HAM kemudian menerbitkan Peraturan Menteri Hukum dan HAM Nomor 10 Tahun 2020 Tentang Syarat Pemberian Asimilasi dan Hak Integrasi Bagi Narapidana dan Anak Dalam Rangka Pencegahan dan Penanggulangan Penyebaran COVID-19. Peraturan lain yang juga diterbitkan untuk mendukung kebijakan pengurangan over kapasitas adalah Keputusan Menteri Hukum dan HAM Nomor 19 Tahun 2020 Tentang Pengeluaran dan Pembebasan Narapidana dan Anak Melalui Asimilasi Dan Integrasi Dalam Rangka Pencegahan Dan Penanggulangan Penyebaran COVID-19.

Peraturan tersebut di atas, menjadi payung hukum bagi pembebasan para narapidana yang telah memenuhi persyaratan. Kedua peraturan memberikan batasan bagi narapidana yang akan memperoleh pembebasan bersyarat melalui asimilasi dan integrasi. Artinya bahwa pembebasan bersyarat sebagai hak bagi narapidana diberikan kepada narapidana yang telah memenuhi persyaratan sebagaimana diatur dalam peraturan yang berlaku salah satunya yaitu diatur dalam Pasal 14 Undang-Undang Nomor 12 tahun 1995 tentang Pemasyarakatan, yang menyatakan bahwa Pembebasan bersyarat adalah bebasnya narapidana setelah menjalani sekurang-kurangnya dua pertiga masa pidananya dengan ketentuan dua pertiga tersebut tidak kurang dari sembilan bulan. 
Pembebasan terhadap narapidana dilakukan dengan pertimbangan rawannya penyebaran COVID-19 di dalam Lembaga Pemasyarakatan (LAPAS), Rumah Tahanan Negara (RUTAN), Lembaga Pembinaan Khusus Anak (LPKA) di Indonesia yang notabene mengalami kelebihan penghuni. Di tengah pandemi COVID-19, penjara menjadi tempat yang berisiko. Persoalannya, selain banyak penjara yang tidak layak huni lantaran minimnya fasilitas dan penyuluhan kesehatan, kelebihan kapasitas juga menyebabkan kebijakan social distancing mustahil untuk diterapkan. Dengan adanya kebijakan untuk membebaskan narapidana yang ada di dalam LAPAS, RUTAN dan LPKA diharapkan dapat mencegah dan menanggulangi penyebaran COVID-19.

Kebijakan pemberian dan pemenuhan hak pembebasan bersyarat terhadap Narapidana di situasi Pandemi COVID-19 berimplikasi pada meningkatnya kriminalitas dimasyarakat. Artinya bahwa upaya dalam rangka pencegahan penyebaran COVID-19 di LAPAS, RUTAN dan LPKA melalui kebijakan regulasi Peraturan Menteri Hukum dan HAM Nomor 10 Tahun 2020 dan Keputusan Menteri Hukum dan HAM Nomor 19 Tahun 2020 Tentang Pengeluaran dan Pembebasan Narapidana dan Anak Melalui Asimilasi Dan Integrasi Dalam Rangka Pencegahan Dan Penanggulangan Penyebaran COVID-19 berimplikasi pada tidak tercapainya tujuan pemidanaan.

Tidak adanya jaminan dari pemerintah bahwa mereka yang diberikan hak integrasi dan asimilasi tidak akan mengulangi kejahatannya, mengingat kehidupan masyarakat di tengah pandemi ini semakin sulit. Maka dapat dikatakan bahwa penerapan kebijakan pembebasan narapidana di tengah COVID-19 ini tidak tepat untuk diterapkan, sehingga membutuhkan kebijakan hukum yang tepat dalam pelaksanaan pembebasan narapidana khususnya di situasi-situasi seperti sekarang ini.

\section{METODE PENELITIAN}

Tipe penelitian yang digunakan yaitu penelitian hukum yang bersifat Normatif, yang merupakan suatu proses untuk menemukan aturan hukum, prinsip-prinsip hukum, maupun doktrin-doktrin hukum guna menjawab isu hukum yang dihadapi yang menghasilkan argumentasi, teori dan konsep baru sebagai preskripsi dalam menyelesaikan masalah yang dihadapi. ${ }^{1}$ Dengan pendekatan penelitian yaitu Pendekatan Undang-Undang (Statute approach), Pendekatan Konseptual (Conceptual approach), Pendekatan Kasus (case approach). Sedangkan sumber bahan hukum yang digunakan

\footnotetext{
1 Peter Mahmud Marzuki, Penelitian Hukum, Jakarta: Kencana Group, 2005, hlm. 35.
} 
adalah bahan hukum primer dan sekunder (studi kepustakaan), dengan analisis yang sifatnya preskripsi.

\section{ANALISIS DAN PEMBAHASAN}

\section{Pandemi COVID-19 Sebagai Alasan Pemberian Pembebasan Bersyarat}

Sistem Pemasyarakatan pada dasarnya merupakan buah pikiran untuk penerapan konsep "Treatment of offender" dan dapat dianggap menggantikan sistem kepenjaraan. ${ }^{2}$ Penempatan narapidana sebagai subjek pembinaan merupakan cerminan dari hak narapidana yang dilindungi oleh negara. Pembinaan ini dilakukan melalui sebuah sistem yang kini dikenal dengan istilah sistem pemasyarakatan. Dalam sistem pemasyarakatan, terpidana disebut dengan istilah warga binaan. Pembinaan yang dilakukan di lembaga pemasyarakatan merupakan sarana untuk mencegah agar warga binaan tidak mengulangi kembali perbuatannya selepas dari lembaga pemasyarakatan. Melalui program-program pembinaan, warga binaan diharapkan dapat kembali diterima oleh lingkungan sosialnya.

Perlindungan dan pemenuhan hak asasi manusia di Lembaga Pemasyarakatan merupakan peran yang sangat strategis dalam merealisasikan tujuan akhir dari sistem peradilan pidana yaitu pembinaan dan pengembalian rasa keadilan yang berdasarkan atas Pancasila, UUD 1945 yakni keadilan yang berperikemanusiaan yang berlandaskan hak asasi manusia kepada pelanggar hukum, bahkan sampai pada penanggulangan kejahatan. ${ }^{3}$

Pembebasan bersyarat merupakan salah satu hak narapidana yang menjadi bagian dari program pembinaan dalam sistem pemasyarakatan, dimana program ini memberikan kesempatan kepada narapidana untuk berintegrasi dengan masyarakatnya lebih cepat. Program ini menjadi alternatiflegal yang dapat membantu Direktorat Jenderal Pemasyarakatan dalam mengurangi masalah kelebihan kapasitas yang terjadi hampir di seluruh LAPAS/RUTAN di Indonesia. ${ }^{4}$

Dalam ketentuan Pasal 43 ayat 1 Peraturan Pemerintah Nomor 99 Tahun 2012 tentang Syarat dan tata cara pelaksanaan hak warga binaan pemasyarakatan, menegaskan bahwa setiap narapidana dan anak didik pemasyarakatan kecuali anak sipil, berhak mendapat pembebasan bersyarat, yang telah memenuhi syarat :

2 H. R. Abdussalam, Sistem Peradilan Pidana, Jakarta: Restu Agung, 2007, hlm. 333.

3 Eko Prasetyo, HAM (Kejahatan Negara dan Imperialisme Modal), Cetakan Pertama, Yogyakarta: Insist Press, 2002, hlm. 19.

4 Marlina, Hukum Penitensier, Bandung: Refika Aditama, 2011, hlm. 124. 
1. Telah menjalani masa Pidana paling singkat $2 / 3$ (dua per tiga), dengan ketentuan 2/3 (dua per tiga) masa Pidana tersebut paling sedikit 9 (Sembilan) bulan;

2. Berkelakuan baik selama menjalani masa Pidana paling singkat 9 (Sembilan) bulan terakhir dihitung sebelum tanggal 2/3 (dua per tiga) masa pidana;

3. Telah mengikuti program pembinaan dengan baik, tekun, dan bersemangat; dan

4. Masyarakat dapat menerima program kegiatan pembinaan Narapidana.

5. Pembebasan Bersyarat dapat diberikan bagi Anak Negara setelah menjalani pembinaan paling sedikit 1 (satu) tahun. ${ }^{5}$

Selanjutnya dalam ketentuan Pasal 82 Peraturan Menteri Hukum Dan Hak Asasi Manusia Republik Indonesia Nomor 18 Tahun 2019 Tentang Peraturan Menteri Hukum Dan Hak Asasi Manusia Republik Indonesia No. 3 Tahun 2018 Tentang Syarat Dan Tata Cara Pemberian Remisi, Asimilasi, Cuti Mengunjungi Keluarga, Pembebasan Bersyarat, Cuti Menjelang Bebas, Dan Cuti Bersyarat bahwa Pembebasan Bersyarat dapat diberikan kepada Narapidana yang telah memenuhi syarat:

a. Telah menjalani masa pidana paling singkat $2 / 3$ (dua per tiga), dengan ketentuan $2 / 3$ (dua per tiga) masa pidana tersebut paling sedikit 9 (sembilan) bulan;

b. Berkelakuan baik selama menjalani masa pidana paling singkat 9 (sembilan) bulan terakhir dihitung sebelum tanggal 2/3 (dua per tiga) masa pidana;

c. Telah mengikuti program pembinaan dengan baik, tekun, dan bersemangat; dan;

d. Masyarakat dapat menerima program kegiatan pembinaan Narapidana.

Narapidana yang dianggap telah memenuhi syarat-syarat sebagaimana ketentuan di atas, mempunyai kemungkinan dapat dikabulkannya permohonan pembebasan bersyaratnya sebelum habis masa pidananya. Narapidana yang dikabulkan permohonan pembebasan bersyaratnya harus menjalani masa percobaan, yaitu selama sisa pidananya yang belum dijalani ditambah satu tahun. Masa percobaan ini merupakan masa peralihan dari kehidupan yang serba terbatas menuju kehidupan bebas sebagai warga yang baik dan bertanggung jawab. Pemberian Pembebasan bersyarat diberikan kepada narapidana yang telah memenuhi syarat-syarat, sehingga pada dasarnya pembebasan bersyarat sangat bermanfaat dan dibutuhkan narapidana dalam rangka memudahkan dirinya menyesuaikan dengan kehidupan masyarakat lingkungannya.

Kebijakan untuk pembebasan narapidana secara bersyarat di tengah pandemi COVID-19 ini dengan alasan kemanusiaan dan sesuai dengan rekomendasi dari PBB.

\footnotetext{
5 Bambang Poernomo. Pidana dan Pemidanaan, Jakarta: Sinar Grafika, 1995, hlm. 77.
} 
Kebijakan tersebut meliputi Peraturan Menteri Hukum dan Hak Asasi Manusia Nomor 10 Tahun 2020 tentang Syarat Pemberian Asimilasi dan Hak Integrasi Bagi Narapidana dan Anak Dalam Rangka Pencegahan dan Penanggulangan Penyebaran COVID-19, serta Keputusan Menteri Hukum dan HAM Nomor 19 Tahun 2020 Tentang Pengeluaran dan Pembebasan Narapidana dan Anak Melalui Asimilasi Dan Integrasi Dalam Rangka Pencegahan Dan Penanggulangan Penyebaran COVID-19. Selain itu, secara teknis kebijakan ini didukung pula dengan aturan-aturan lainnya yakni:

1) Instruksi Direktur Jenderal Pemasyarakatan Nomor: PAS- 08.0T.02.02 Tahun 2020 tanggal 17 Maret 2020 tentang Pencegahan, Penanganan, Pengendalian dan Pemulihan COVID-19 pada Unit Pelaksanaan Teknis Pemasyarakatan.

2) Surat Edaran Direktur Jenderal Pemasyarakatan Nomor PAS516.PK.01.04.06 Tahun 2020 Tentang Mekanisme Pelaksanaan Peraturan Menteri Hukum Dan Hak Asasi Manusia Nomor 10 Tahun 2020 Tentang Syarat Pemberian Asimilasi Dan Hak Integrasi Bagi Narapidana Dan Anak Dalam Rangka Pencegahan Dan Penanggulangan Penyebaran COVID-19.

3) Surat Edaran Direktur Jenderal Pemasyarakatan Nomor: PAS.497.PK.01.04.04 Tahun 2020 tanggal 31 Maret 2020 tentang Pengeluaran dan Pembebasan Narapidana dan Anak melalui Asimilasi dan Integrasi dalam rangka Pencegahan dan Penanggulangan Penyebaran COVID-19.

4) Surat Edaran Direktur Jenderal Pemasyarakatan Nomor: PAS.20.PR.01.01 Tahun 2020 tanggal 26 Maret 2020 tentang Langkah Progresif dalam Penanggulangan Penyebaran COVID-10 pada UPT Pemasyarakatan.

Merujuk pada ketentuan UU Pemasyarakatan sebetulnya asimilasi dan integrasi merupakan tahapan pemasyarakatan sebagaimana pengertian dari asimilasi itu sendiri yakni "proses pembinaan narapidana dan anak yang dilaksanakan dengan membaurkan narapidana dan anak dalam kehidupan masyarakat". Pelaksanaannya tidak bergantung pada faktor eksternal semisal adanya pandemi COVID-19 ataupun tidak. Berbeda dengan asimilasi, hak integrasi merupakan bagian dari pembebasan bersyarat. Sesuai dengan bunyi Pasal 1 Angka 5 Permenkumham 10 Tahun 2020 bahwa "pembebasan bersyarat, cuti menjelang bebas, dan cuti bersyarat adalah program pembinaan untuk mengintegrasikan narapidana dan anak ke dalam kehidupan masyarakat setelah memenuhi persyaratan yang telah ditentukan".

Penerapan kebijakan pembebasan narapidana di tengah pandemi COVID-19 ini dapat dikatakan belum sepenuhnya tepat. Penilaian ini didasarkan pada fakta, dimana kebijakan ini memicu dan memunculkan permasalahan baru, dimana justru mengancam tujuan sebenarnya dari kebijakan itu sendiri. Fakta yang terjadi bahwa masyarakat diresahkan dengan sederet kasus tindak pidana yang dilakukan oleh beberapa narapidana 
yang memperoleh pembebasan bersyarat melalui program hak asimilasi dan hak integrasi. Meskipun diketahui bahwa pengulangan tindak pidana atau residivis bukanlah menjadi hal yang baru dalam dunia hukum. Yang mana pengulangan tindak pidana tersebut dianggap sebagai kelanjutan dari niat jahat atau terjadinya perbuatan melawan hukum oleh pelaku yang notabenenya pernah menjadi narapidana.

Hal ini menjadi lebih mengkhawatirkan ketika terjadi dalam keadaan situasi pandemi COVID-19 seperti saat ini. Narapidana yang dibebaskan tidak serta merta menjamin terhindar dari kesulitan dalam memenuhi kebutuhan hidupnya, yang salah satunya dikarenakan susahnya mencari pekerjaan sehingga besar potensi bagi eksnarapidana untuk melakukan tindak pidana kembali. Walaupun dengan alasan sebagai pemenuhan kebutuhan hidup, hal itu tidak dapat dijadikan alasan pembenaran bagi eksnarapidana yang telah melakukan tindak pidana tersebut, apalagi jika telah menimbulkan keresahan di masyarakat. Selain sebagai pemenuhan kebutuhan hidup, faktor lain yang mendorong terjadinya residivis ialah belum efektifnya fungsi pengawasan oleh Balai Pemasyarakatan (BAPAS), hal ini dikarenakan masih terbatasnya sumber daya manusia dalam lembaga ini dan diketahui bahwa BAPAS tidak melakukan pembinaan dengan cara seperti biasanya, saat ini hanya mengandalkan teknologi yang ada, sehingga tidak dapat memberikan pelayanan secara optimal.

Tujuan dibentuknya kebijakan hukum yaitu Peraturan Menteri Hukum dan Hak Asasi Manusia Nomor 10 Tahun 2020 tentang Syarat Pemberian Asimilasi dan Hak Integrasi Bagi Narapidana dan Anak Dalam Rangka Pencegahan dan Penanggulangan Penyebaran COVID-19, serta Keputusan Menteri Hukum dan HAM No. 19 Tahun 2020 tentang Pengeluaran dan Pembebasan Narapidana dan Anak Melalui Asimilasi dan Integrasi dalam Rangka Pencegahan dan Penanggulangan Penyebaran COVID-19 adalah dimaksudkan untuk menjamin narapidana terhindar dari paparan COVID-19 akibat kondisi LAPAS yang overcrowded, justru penerapan kebijakan ini akan berakibat sebaliknya, karena dapat dikatakan kecil kemungkinannya terjadi penyebaran COVID-19 jika narapidana tetap berada di LAPAS, sebab mereka tidak mendapati kontak langsung dengan orang luar.

\section{Konstruksi Kebijakan Hukum Pidana Pemberian Pembebasan Bersyarat Di Situasi Pandemi COVID-19}


Kebijakan pengeluaran dan pembebasan narapidana melalui proses asimilasi dan integrasi menuai kontroversi. Tidak hanya pembebasan narapidana umum, namun wacana pembebasan narapidana khusus juga ikut menjadi kontroversi. Sebagian kalangan menilai keputusan tersebut merupakan langkah yang tepat guna menghormati hak asasi manusia dalam sistem peradilan pidana. Di sisi lain, tidak sedikit yang justru menyayangkan keputusan tersebut dengan berbagai alasan, khususnya kekhawatiran akan dampak kerentanan aspek sosial dan keamanan selepas narapidana tersebut bergerak bebas di masyarakat. Publik merasa ragu bahwa upaya pembebasan narapidana merupakan langkah yang tepat dalam mencegah penyebaran dan penularan COVID-19.

Kebijakan peraturan Menteri Hukum dan HAM tersebut bersifat mutatis mutandis dengan kebijakan terhadap para narapidana koruptor yang diwacanakan akan memperoleh pembebasan bersyarat. Penolakan ini terjadi arus yang sangat deras karena selama ini Lembaga Permasyarakatan yang diperuntukkan untuk penghuni narapidana koruptor tidak over crowded atau over capacity seperti dalam LAPAS tindak pidana umum yang lain.

Dalam rangka mempertimbangkan potensi besar penularan COVID-19 dalam kondisi overcrowding, pemerintah mengambil beberapa kebijakan, yang secara umum dapat dikelompokkan ke dalam 3 kategori yaitu sebagai berikut:

1) Melakukan tindakan preventif masuknya tahanan baru.

2) Memperketat protokol pencegahan di dalam LAPAS dan RUTAN

3) Menurunkan potensi penularan dengan mengurangi jumlah narapidana melalui percepatan pengeluaran.

Munculnya berbagai pemberitaan yang menyebutkan bahwa pelepasan narapidana akibat kebijakan asimilasi dan integrasi menyebabkan adanya residivis yang melakukan kembali kejahatan jalanan (mengulang perbuatan kejahatan) di masyarakat, semestinya menjadi catatan juga bagi Pemerintah (khususnya Kementerian Hukum dan HAM RI) melakukan evaluasi khusus terkait kebijakan asimilasi dan integrasi, dimana kebijakan tersebut harus didasarkan juga pada catatan penilaian risiko terhadap masingmasing narapidana maupun warga anak binaan. Hal ini untuk meminimalisasi risiko eksnarapidana atau warga binaan mengulang kembali tindakan yang salah di masyarakat.

Pembebasan narapidana untuk mengurangi penyebaran COVID-19 di tengah padatnya LAPAS merupakan solusi yang kurang tepat dan hanya bersifat sementara. Penyebab utama penularan penyakit di tahanan yang over kapasitas adalah kebijakan 
pemerintah yang masih mengutamakan hukuman penjara dalam penegakan hukum untuk memberi efek jera bagi seseorang yang tersangkut kasus hukum. Besarnya persentase penggunaan penjara dalam peraturan perundang-undangan dan penjatuhan pidana tidak diimbangi dengan sarana prasarana yang mencukupi. Selama pemerintah tidak mengubah kebijakan penegakan hukum dalam bentuk penahanan dan pemenjaraan maka LAPAS dan RUTAN akan selalu padat dan berisiko dalam penyebaran virus.

Persoalan residivisme yang dilakukan para napi program asimilasi dan integrasi menuntut pembenahan proses penindakan hukum. Salah satunya terkait dengan pendekatan pemidanaan yang tak perlu lagi berdasarkan perspektif balas dendam. Problem yang dihadapi oleh LAPAS saat ini adalah dampak sistemis dari perundangundangan dan sistem hukum pidana di Indonesia. Karena tidak semua tindak pidana efektif dilakukan dengan cara pemenjaraan. Pendekatan restorative justice perlu diterapkan sebagai salah satu jalan keluar. Oleh karena itu, dalam kondisi pandemi COVID19 saat ini, harusnya bisa menjadi momentum untuk mendorong perubahan sistem penegakan hukum pidana. Adanya residivis justru membuktikan bahwa untuk tindak pidana tertentu, pemidanaan atau penjara itu tidak efektif, melainkan perlu diterapkan restorative justice.

Melihat dampak yang timbul, pembebasan narapidana jangan hanya difokuskan untuk sekedar mencegah COVID-19, namun tetap harus memperhatikan aspek keadilan dan efek jera sebagai tujuan pemidanaan. Hal ini sesuai dengan teori pemidanaan relatif yang dikemukakan oleh Muladi, di mana pemidanaan bukan sebagai pembalasan atas kesalahan pelaku tetapi sarana mencapai tujuan yang bermanfaat. Tujuan pemidanaan dilakukan untuk memperbaiki pelaku agar menjadi baik dan tidak mengulangi kejahatannya kembali. ${ }^{6}$

Sehingga menurut penulis, bahwa dalam konsepsi pendekatan kebijakan, penerapan restorative justice adalah sebagai upaya mengurangi over kapasitas penjara. Konsep restorative justice merupakan suatu pendekatan yang lebih menitikberatkan pada kondisi terciptanya keadilan dan keseimbangan bagi para pelaku tindak pidana serta korban. Mekanisme tata cara dan peradilan pidana yang berfokus pada pemidanaan diubah menjadi proses dialog dan mediasi untuk menciptakan kesepakatan atas penyelesaian perkara pidana yang lebih adil dan seimbang bagi korban dan pelaku. ${ }^{7}$

\footnotetext{
6 Natangsa Surbakti, Peradilan Restoratif dalam Bingkai Empiri, Teori dan Kebijakan, Yogyakarta: Genta Publishing, 2014, hlm. 211.

7 Ibid.
} 
Konsepsi pelaksanaan kebijakan pembebasan bersyarat disituasi pandemi COVID-19, seharusnya dibangun berdasarkan konsepsi pembaruan hukum pidana yang telah jauh mengalami pergeseran paradigma, sehingga ada karakteristik yuridis yang terbentuk dalam rangka pemenuhan hak serta di satu sisi adalah sebagai bentuk pembinaan terhadap hak tersebut. Sebagai contoh seperti Karakteristik yuridis yang terkandung dalam undang-undang tindak pidana korupsi, secara keseluruhan telah menggambarkan adanya dinamika pembaharuan hukum pidana dalam pemberantasan tindak pidana korupsi. ${ }^{8}$

Saat ini paradigma hukum pidana telah bergeser dari yang semula retributif atau menekankan pada pembalasan, sekarang lebih menekankan pada pendekatan korektif, rehabilitatif dan restoratif. Korektif artinya memberikan koreksi pada pelaku agar menyadari kesalahan yang dilakukan, meminta maaf dan tindak mengulangi kembali kejahatan tersebut. Rehabilitatif lebih kepada memperbaiki pelaku serta restoratif artinya memulihkan kembali ke keadaan semula (restutio in integrum), dimana keadaan sempat terganggu akibat terjadinya kejahatan.

Dilihat dari sudut pendekatan kebijakan, pembebasan bersyarat demi penanggulangan COVID-19 melalui Peraturan Menteri Hukum dan HAM No. 10 Tahun 2020 tentang Syarat Pemberian Asimilasi dan Hak Integrasi bagi Narapidana dan Anak dalam Rangka Pencegahan dan Penanggulangan Penyebaran COVID-19 serta Keputusan Menteri Hukum dan HAM No. M.HH-19.PK.01.04.04/2020 tentang Pengeluaran dan Pembebasan Narapidana dan Anak Melalui Asimilasi dan Integrasi dalam Rangka Pencegahan dan Penanggulangan Penyebaran COVID-19, merupakan bagian dari upaya untuk mengatasi masalah-masalah sosial dalam hal ini COVID-19 merupakan masalah kemanusian dan juga merupakan bagian dari upaya memberikan perlindungan kepada masyarakat.

Sehingga sangat tegas bahwa hukum pidana harus disepadankan dengan kebutuhan untuk melindungi dan mempertahankan kepentingan-kepentingan masyarakat. Maka sangat tepat bahwa pembaharuan hukum pidana harus dilakukan dengan pendekatan kebijakan, karena pada hakikatnya pembaharuan hukum merupakan suatu langkah kebijakan atau policy yang merupakan bagian dari politik hukum (penegakan hukum), politik hukum pidana, politik kriminal dan politik sosial.

8 Sabrina Hidayat, "Tinjauan Yuridis Kewenangan Komisi Pemberantasan Korupsi Melakukan Penyidikan Penggabungan Perkara Tindak Pidana Korupsi dan Pencucian Uang”, Halu Oleo Law Review, Volume 1 Issue 2, September 2017, hlm. 180-195. 
Di sisi lain, dalam konsepsi pendekatan yang rasional, Peraturan Menteri Hukum dan HAM No. 10 Tahun 2020 tentang Syarat Pemberian Asimilasi dan Hak Integrasi bagi Narapidana dan Anak dalam Rangka Pencegahan dan Penanggulangan Penyebaran COVID19 serta Keputusan Menteri Hukum dan HAM No. M.HH-19.PK.01.04.04/2020 tentang Pengeluaran dan Pembebasan Narapidana dan Anak Melalui Asimilasi dan Integrasi dalam Rangka Pencegahan dan Penanggulangan Penyebaran COVID-19, harus dilihat sebagai sarana untuk menanggulangi kejahatan harus benar-benar telah memperhitungkan semua faktor yang dapat mendukung dan berfungsi dan bekerjanya aturan sebagai ketentuan dalam kenyataannya.

Kebijakan Peraturan Menteri Hukum dan HAM No. 10 Tahun 2020 tentang Syarat Pemberian Asimilasi dan Hak Integrasi bagi Narapidana dan Anak dalam Rangka Pencegahan dan Penanggulangan Penyebaran COVID-19 serta Keputusan Menteri Hukum dan HAM No. M.HH-19.PK.01.04.04/2020 tentang Pengeluaran dan Pembebasan Narapidana dan Anak Melalui Asimilasi dan Integrasi dalam Rangka Pencegahan dan Penanggulangan Penyebaran COVID-19, dapat dikatakan bermasalah pada tahapan eksekusi secara administratif, karena adanya pembatasan bagi napi yang bisa dan tidak bisa mendapatkan pembebasan bersyarat, karena hal diberikan kepada napi yang memenuhi ketentuan yang berlaku. Pada tahapan eksekusi ini, kebijakan pembebasan bersyarat disituasi pandemi COVID-19 mempunyai permasalahan, karena pada tahap implementasinya kebijakan ini tidak begitu efektif.

Dilain sisi, masyarakat adalah salah satu faktor penting keberhasilan kebijakan asimilasi dan hak integrasi. Undang-undang Nomor 12 tahun 1995 tentang Pemasyarakatan pada Pasal 1 ayat 2 menekankan bahwa "sistem pemasyarakatan adalah suatu tatanan mengenai arah dan batas serta cara pembinaan warga binaan pemasyarakatan berdasarkan Pancasila yang dilaksanakan secara terpadu antara pembina, yang dibina, dan masyarakat untuk meningkatkan kualitas warga binaan pemasyarakatan agar menyadari kesalahan, memperbaiki diri, dan tidak mengulangi tindak pidana sehingga dapat diterima kembali oleh lingkungan masyarakat, dapat berperan aktif dalam pembangunan, dan dapat hidup secara wajar sebagai warga yang baik dan bertanggung jawab".

Namun realitasnya, peran serta masyarakat dalam menerapkan proses pembinaan warga binaan pemasyarakatan atau napi sangat minim. Faktor penunjangnya adalah atau ditunjang oleh ketidakpedulian masyarakat terhadap mantan narapidana 
dengan enggan menerima keberadaannya. Hal ini tentunya menghambat tercapainya tujuan pemidanaan yang diharapkan. Maka tanpa ada pera serta masyarakat dengan sedikitnya mengurangi stigma negatif bagi para manta narapidana, tujuan sistem pemasyarakatan dengan upaya reintegrasi narapidana melalui asimilasi dan hak integrasi tidak akan tercapai. Dimana proses pembinaan seharusnya berfungsi menyiapkan warga binaan pemasyarakatan agar dapat berintegrasi secara sehat dengan masyarakat, sehingga dapat berperan kembali sebagai anggota masyarakat yang bebas dan bertanggung jawab.

Peran serta masyarakat yang mempunyai potensi dalam bidang pelaksanaan kegiatan kerja sangat dibutuhkan guna menunjang keberhasilan dari program pembinaan yang telah ditentukan. Dalam melakukan pembinaan terhadap narapidana diperlukan program pembinaan yang menunjang ke arah integrasi dengan masyarakat. Seluruh proses pembinaan narapidana selama proses pemasyarakatan merupakan satu kesatuan yang integral guna menuju kepada tujuan mengembalikan narapidana ke masyarakat bebas dengan bekal kemampuan (mental, fisik, keahlian, keterampilan, sedapat mungkin finansial dan materi) yang dibutuhkan untuk menjadi warga negara yang baik dan berguna.

\section{KESIMPULAN}

Penerapan kebijakan pembebasan narapidana di tengah pandemi COVID-19 belum sepenuhnya tepat. Kebijakan ini memicu dan memunculkan permasalahan baru, yaitu mengancam tujuan sebenarnya dari kebijakan itu sendiri. Kebijakan pembebasan narapidana guna mencegah penularan dan penyebaran COVID-19 bukan solusi yang tepat dan hanya bersifat sementara. Persoalannya bukan pada over kapasitas LAPAS dan RUTAN melainkan pada kebijakan pemerintah yang lebih mengutamakan hukuman penjara dalam penegakan hukum. Sehingga membutuhkan konstruksi kebijakan yang tepat. Selain itu, konsepsi pelaksanaan kebijakan pembebasan bersyarat disituasi pandemi COVID-19, seharusnya dibangun berdasarkan konsepsi pembaruan hukum pidana yakni dilihat dari sudut pendekatan-kebijakan, pembebasan bersyarat demi penanggulangan COVID-19, merupakan bagian dari upaya untuk mengatasi masalah-masalah sosial dalam hal ini COVID-19 merupakan masalah kemanusian dan juga merupakan bagian dari upaya memberikan perlindungan kepada masyarakat, serta jika dilihat dari sudut pendekatan yang rasional, seharusnya jangan hanya dinilai sebagai bentuk pencegahan COVID-19 
tetapi harus dilihat sebagai sarana untuk menanggulangi kejahatan yang harus benarbenar telah memperhitungkan semua faktor yang dapat mendukung dan berfungsi dan bekerjanya aturan sebagai ketentuan dalam kenyataannya.

\section{Daftar Pustaka}

\section{Buku}

Abdussalam, H. R., Sistem Peradilan Pidana, Jakarta: Restu Agung, 2007.

Marlina, Hukum Penitensier, Bandung: Refika Aditama, 2011.

Marzuki, Peter Mahmud, Penelitian Hukum, Jakarta: Kencana Group, 2005.

Poernomo. Bambang. Pidana dan Pemidanaan, Jakarta: Sinar Grafika, 1995.

Prasetyo, Eko, HAM (Kejahatan Negara dan Imperialisme Modal), Cetakan Pertama, Yogyakarta: Insist Press, 2002.

Surbakti, Natangsa, Peradilan Restoratif dalam Bingkai Empiri, Teori dan Kebijakan, Yogyakarta: Genta Publishing, 2014.

\section{Jurnal dan Makalah}

Hidayat, Sabrina, Tinjauan Yuridis Kewenangan Komisi Pemberantasan Korupsi Melakukan Penyidikan Penggabungan Perkara Tindak Pidana Korupsi dan Pencucian Uang, Halu Oleo Law Review, Volume 1 Issue 2, September 2017. hlm. 180-195.

\section{Peraturan Perundang-undangan}

Undang-Undang Nomor 12 tahun 1995 tentang Pemasyarakatan.

Peraturan Pemerintah Nomor 99 Tahun 2012 tentang Syarat dan Tata Cara Pelaksanaan Hak Warga Binaan Pemasyarakatan.

Peraturan Menteri Hukum Dan Hak Asasi Manusia Republik Indonesia Nomor 18 Tahun 2019 tentang Perubahan atas Peraturan Menteri Hukum Dan Hak Asasi Manusia Republik Indonesia Nomor 3 Tahun 2018 dengan Tentang Syarat Dan Tata Cara Pemberian Remisi, Asimilasi, Cuti Mengunjungi Keluarga, Pembebasan Bersyarat, Cuti Menjelang Bebas, Dan Cuti Bersyarat.

Peraturan Menteri Hukum dan HAM RI (Permenkumham) Nomor 10 Tahun 2020 tentang Syarat Pemberian Asimilasi dan Hak Integrasi Bagi Narapidana dan Anak Dalam Rangka Pencegahan dan Penanggulangan Penyebaran COVID-19. 
Keputusan Menteri Hukum dan HAM RI No.M.HH-19 PK.01.04.04 Tahun 2020 tentang Pengeluaran dan Pembebasan Narapidana dan Anak Melalui Asimilasi dan Integrasi Dalam Rangka Pencegahan Dan Penanggulangan Penyebaran COVID-19. 